Canadian Journal of Higher Education

Revue canadienne d'enseignement supérieur

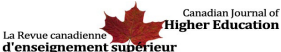

\title{
Stead, Virginia (Ed.) (2017). A Guide to LGBTQ+ Inclusion on Campus, Post-PULSE
}

\section{Kristin Hocker}

Volume 49, Number 2, 2019

URI: https://id.erudit.org/iderudit/1063784ar

DOI: https://doi.org/10.7202/1063784ar

See table of contents

Publisher(s)

Canadian Society for the Study of Higher Education

ISSN

2293-6602 (digital)

Explore this journal

Cite this review

Hocker, K. (2019). Review of [Stead, Virginia (Ed.) (2017). A Guide to LGBTQ+ Inclusion on Campus, Post-PULSE]. Canadian Journal of Higher Education /

Revue canadienne d'enseignement supérieur, 49(2), 118-122.

https://doi.org/10.7202/1063784ar viewed online.

https://apropos.erudit.org/en/users/policy-on-use/ 


\section{CSSHE SCÉES}

Canadian Journal of Higher Education Revue canadienne d'enseignement supérieur

Volume 49, No. 2, 2019, pages 118 - 122

\section{Book Reviews / Comptes Rendus}

\section{Stead, Virginia (Ed.) (2017). A Guide to LGBTQ+ Inclusion on Campus, Post-PULSE. New York: Peter Lang. Pages: 340. Price: 54.95 USD (paper).}

Reviewed by Kristin Hocker, Assistant Professor of Clinical Nursing, University of Rochester School of Nursing.

On June 12, 2016, the world awoke to news of the mass shooting at PULSE nightclub, a haven for the LGBTQ+ community in Orlando, Florida, and attempted to make sense of the senseless through their collective grief, fear, and outrage. In A Guide to LGBTQ+ Inclusion on Campus, Post-PULSE, volume seven in Virginia Stead's Equity in Higher Education series, the authors make sense of tragedy by contributing personal stories and strategies to inspire colleges and universities to incorporate LGBTQ+ inclusive practices on their campuses.

While the title refers to post-PULSE LGBTQ+ inclusion, the book's premise is to "transform LGBTQ+ exclusion into inclusion" (p.1). This call to action recognizes that exclusion has existed before PULSE occurred and is symptomatic of the persistent influences of heterosexism, homophobia, genderism, and racism that culminate both in monumental tragedies such as the PULSE shooting, as well as daily experiences of marginalization that contribute to an ongoing uncertainty of safety and sense of belonging. A Guide to LGBTQ+ Inclusion on Campus, Post-PULSE responds to this 
call for action with a blend of autoethnographic narratives, case studies, and equity-conscious strategies that address the systemic and interpersonal manifestations of oppression and build inclusive practices.

The book divides 24 chapters into six major sections, including an afterword and the authors' profiles. Given the number of chapters, in this review I will highlight the chapters that best reflect each section's theme. The book begins with a moving memorial to the 49 souls whose lives were taken in the PULSE tragedy, grounding the book's purpose and urgency for action. Warren Blumenfeld then provides a brief, historical landscape in the book's forward, using his personal coming out story to illustrate significant changes of LGBTQ+ inclusivity over the past 50 years. Ending on a hopeful note, he acknowledges the need for solidarity in the struggle for advancing LGBTQ+ equity.

The first section (Chapters 1-4) expands the idea of campus beyond classrooms, quads and resident halls to include often overlooked areas that also compose a campus, including its neighboring community. Robin Fox and Erica Schepp (Chapter 2) consider the impact of incorporating LGBTQ+ inclusive topics within a campus children's center curriculum as a means of affirming and normalizing the experiences of children whose families identify along the spectrum. Dominic Grasso and Traci Baxley (Chapter 3) propose that LGBTQ+ inclusive curriculum in early children's education could encourage children to become more self-reflective and engaged in their communities while developing strategies to disrupt bullying. The authors imagine the impact of inclusive early education on families and the capacity to generate a widespread cultural practice of disrupting inequity.

Section Two (Chapters 5-8) examines the multiple ways exclusion occurs on campus and the ideological underpinnings of exclusion. Both valerie guerrero and Kari Dockendorff (Chapter 5) and S. Gavin Weiser and Travis Wagner (Chapter 6) reveal the power dynamics that emerge between institutional decision makers and the institutional community members when universities fail 
to support their stakeholders' interests for inclusion. Using cases such as bestowing honorary degrees on individuals associated with hate groups, the authors caution institutions to consider how such actions can contradict their commitment for inclusion, and instead maintain the status quo of heteronormativity. Wahinkpe Topa (Chapter 7) highlights the ideological underpinning of discrimination by challenging the religious doctrines that instigate the idea that LGBTQ+ identities are unnatural. He provides a counter-narrative using an Indigenous worldview to describe the existence of two-spirit as a reflection of nature's balance that embraces alternative sexual identities.

The authors in Section Three (Chapters 9-12) use autoethnography to share their narratives of exclusion, while reflecting on their multiple identities and their ability to be authentically present within the spaces they occupy, specifically noting their shifted sense of safety and belonging in their immediate communities after PULSE. Sarah Pickett (Chapter 9) explores the political nature of her queer identity in relation to being a parent and educator, while reflecting on her need for her children's school and the campus where she is employed to have demonstrated an "ethics of care" (p. 99) by acknowledging the tragedy the morning after, thus signaling her visibility.

Karen Huchting, Jill Bickett, and Emily Fisher (Chapter 13) and Angela Clark-Taylor, Kaitlin Legg, Carissa Cardenas, and Rachael Rehage (Chapter 14) contribute to Section Four's focus on building LBGTQ+ inclusive leadership education and training. In Chapter 13, the authors suggest incorporating curricular approaches to teach about heterosexism and how it operates, as a means for educational leaders to deconstruct heterosexual privilege in their work and lives. The authors in Chapter 14 introduce a new acronym, "minortized identities of sexuality and gender" (MIoSG) (p. 157), and champion for integrating MIoSG topics into student affairs education programs, preparing professionals to better serve students along the spectrum.

Section Five (Chapters 15-18) transitions from investigating 
personal experiences with exclusion towards focusing on institutional practices of inclusion by exploring the external and internal influences that motivate institutions to adopt LGBTQ+ inclusive policies. Using the case of George Washington University's (GW) response to hate crimes, Carol Kochhar-Bryant (Chapter 15) applies an equity-minded conceptual framework to describe GW's efforts in revisiting and fixing their practices, policies, and expectations to remedy the effects of hate crimes on their community (p. 185). The adoption of inclusive policies in turn contributed to increasing resources for student support, and the incorporation of academic programming. For Nicole Bedera and Kristjane Nordmeyer (Chapter 17) equity occurs when colleges adopt a victim-centered approach to providing support to queer survivors of sexual assault by focusing on the students' needs while restructuring practices, resources, and spaces that could ensure safety for LGBTQ+ survivors.

Lastly, the authors in Section Six (Chapters 19-24) provide examples of incorporating LGBTQ+ inclusive pedagogy with the goal of eradicating marginalization. Brandon Beck, Katherine Lewis, and Susan Croteau (Chapter 20) propose using critical pedagogy to frame gender-complex education that can render transgender identities visible. In Chapter 21, Laura Gentner and Kristen Altenau Keen promote incorporating activities within ally training in which participants practice active allyship, shifting from the passive notion of ally as identity, toward ally as a verb. Pamela Ross McClain (Chapter 24) concludes the section reminding readers of the book's purpose by listing the names and ages of the 49 who were killed.

This book serves as a useful resource for professionals in higher education seeking to transform exclusion into inclusion on their campuses, either as scholar-practitioners, staff who coordinate programming or services, or student leaders seeking ways to be inclusive. The use of personal narratives emphasizes that the personal is political and that inclusive practices provide members of our institutional community a sense of safety in spaces where they can thrive. 
While the book was expansive in its diverse range of voices, there is always the risk in knowing that not all identities and their perspectives are included. Subsequent volumes might consider which identities still need to be heard. This may include addressing the absence of identities along the acronym who tend be overlooked, with consideration to how their narratives might contribute to the wealth of knowledge needed to transform campuses. Regardless of the gaps, A Guide to LGBTQ+ Inclusion on Campus, Post-PULSE is a beneficial resource for anyone eager to enact LGBTQ+ inclusion on their campus. 